\title{
Index of Individuals, Groups and Places
}

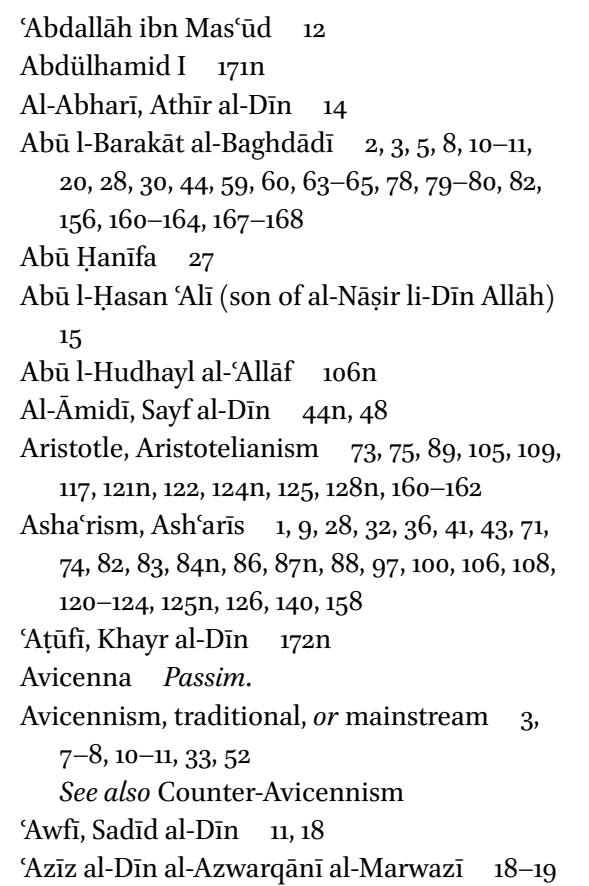

Baghdad 1on, 15, 19

Al-Baghdādī, 'Abd al-Qāhir 32

Al-Baghdādī, Abū l-Barakāt See Abū

l-Barakāt al-Baghdādī

Bahmanyār ibn al-Marzubān $\quad 8,14,25$, 117, 119, 163

Bahshamīs See Mu'tazila

Bașran Mu'tazila See Mu'tazila

Bāyezid II 172

Al-Bayhaqī, Zahīr al-Dīn $\quad 8$, 10, 11, 47, 48, 169

Al-Bīrūnī 23

Bukhara $\quad 2,12,15^{-16,17,18,19, ~} 107$

Cairo 13, 27

Counter-Avicennism $\quad 3,8-10,11,25,28-33,5^{2}$

Al-Dabūsī, Abū Zayd $\quad 27$

Damascus 13n

Daqāyiqī, Shams al-Dīn $\quad 17$

Euclid 44
Fakhr al-Dīn al-Rāzī See al-Rāzī, Fakhr al-Dīn

Al-Fārābī 171

Farāmarz ibn 'Alī, 'Alā' al-Dawla $\quad 8,11$

Al-Fārisī, Kamal al-Dīn $\quad 22$

Fāshān 19n

Al-Fāshānī, Ismācēl ibn Muhammad 19

Galen 2, 45, 46

Gharawiyya Library 17

Al-Ghazālī 1, 2, 3, 5, 8, 9-10, 11, 18, 20, 26, 27, $28,30,31,32-33,41,43,44,46 \mathrm{n}, 57,7 \mathrm{nn}$, 71, 72, 73, 74n, 78, 81-82, 83-85, 95-98, $105-106,107,108,110,120-126,127-128,129$, 132, 134n, 135-136, 137-138, 139, 140, 142, 143, 149-150, 152, 153, 155, 163, 166

Ghazna 107n

Ghaznavids 7

Al-Ghaznawī, Muhammad ibn Mas'ūd 2n, $25 \mathrm{n}$

Al-Gulbarī, Mas‘ūd ibn Muḥammad 172

Ḥanafism 26-27, 33n

Al-Ḥarithān al-Sarakhsī $\quad 48 \mathrm{n}$

Al-Ḥasan al-Ṣabbāḥ $\quad$ 28, 32-33

Herat 19

Hilla 15

Ḥilmī Zāde, Awḥad al-Dīn 173

Ibn al-Akfānī 13

Ibn al-Bāqillānī al-Naḥwī al-Ḥillī $\quad 15$

Ibn Ghaylān al-Balkhī $\quad 3,8,10,11,13,16,18$, $24-26,29-30,33,47,83-84,128 \mathrm{n}, 163$

Ibn al-Haytham $\quad 2,23,45,46 n, 169$

Ibn Khaldūn $85 \mathrm{n}$

Ibn Zayla $48 \mathrm{n}$

Al-İjī, 'Aḍud al-Dīn 142

Al-Īlāqī, Sharaf al-Zamān $\quad 8$

Isfarāīin $\quad 169$

Al-Isfarāīnī, Fakhr al-Dīn $\quad 48$

Ismāîlism $\quad 9,28-29$

Al-Jubbā'ī, Abū Hāshim 86, 106n

Al-Jurjānī, al-Sayyid al-Sharīf $\quad 142$

Jürabdh $\quad 169$

Al-Jūrabdhī, Sharaf al-Dīn $\quad 169$ 
Al-Juwaynī 9, 42n, 88, 97, 123

Al-Jūzjānī $\quad 48 n$

Kākūyids $\quad 8,11$

Karmīniyya $\quad 15$

Karrāmiyya $106 \mathrm{n}$

Al-Kāshī, Ghiyāth al-Dīn $\quad 22 n$

Al-Kāshī, Afḍal al-Dīn $\quad 2 n$

Kātib Çelebī 26

Al-Kharaqī 13, 23

Khārijism 43

Al-Khayyām, 'Umar $\quad 8,11,13-14,49$

Khurasan 7, 8, 12, 15, 16, 17, 169

Khūzistān $\quad 15$

Al-Kindī 171

Kūshyār ibn Labbān $\quad 23$

Khwārazm 7

Khwārazm-shāhs $\quad 7,18$

Al-Khwārazmī, Maḥmūd $\quad 8$

Al-Lawkarī $\quad$ 8, 23n, 163

Maḥmūd I 172

Mahmūd ibn Muhammad ibn 'Abd al-Karīm See Taj al-Dīn Maḥmūd ibn Muhammad

Marw 7, 8, 12, 13, 14, 15, 16, 18-19, 23, 27

Mas'ūd ibn al-Ḥasan Qarākhān 16, 24

Al-Mas'ūdī, Abū 'Abdallāh Muhammad ibn

'Abdallāh 12, 13n

Al-Mas'ūdī, Abū l-Faḍl Muhammad ibn Sa'īd 12,13

Al-Mas'ūdī, Abū l-Fath Mas'ūd ibn Muhammad 13

Al-Mas'ūdī, Sharaf al-Dīn $\quad$ Passim.

Māturīdism, Māturīdīs 72n, 100, 106-107, 108

Miskawayh $\quad 169$

Al-Mișrī, Quțb al-Dīn 14

Mullā Șadrā 4, 172

Mu'tazila 9, 41, 43, 86-88, 93, 100, 106n, 108, 158,159

Al-Muzanī 12

Najaf 17

Al-Nāṣir li-Dīn Allāh $\quad 15$

Al-Naz̧z̄ām 159

Neoplatonism 40, 74, 83, 9on

Al-Nīsābūrī, Mas'ūd ibn Muhammad 26n

Al-Nīsābūrī, Raḍī al-Dīn $\quad$ 16, 18, 26

Nishapur $7,8,14,19$
Nizāminya College 13

Oghuz $7,16,23$

Philoponus, John 148

Ptolemy 2, 45

Al-Qaffāl $\quad 12$

Al-Qaffāl al-Shāshī $\quad 12 n$

Qarā Khitāi 8

Qarākhānids $7,16-17,21$

Al-Qaț̣ān al-Marwazī 13, 23

Qațwān 8

Al-Qazwīnī, Rukn al-Dīn $\quad$ 18n, 26

Qurān 4on, 43

Rayy 19

Al-Rāzī, Abū Bakr $\quad$ 2, 45, 46

Al-Rāzī, Fakhr al-Dīn $\quad$ VII, 1, 2, 3-5, 11-12, 14, $17,18,19,20,21,27,28-29,30-33,44 \mathrm{n}, 47$, 48, 49, 51, 52, 55, 57, 58-59, 6o, 61, 62n, 65, $70,78 \mathrm{n}, 8 \mathrm{o}, 83,93,99,106 \mathrm{n}, 107,118,120$, 121n, 141, 142, 143-144n, 155, 163, 164, 167, 174

Al-Ṣābūnī, Nūr al-Dīn $\quad 107$

Șadaqa, Zayn al-Dīn $\quad$ 49n

Al-Ṣafadī 13, 15

Saī̀ al-Su'adā', Khānqāh 13

Al-Șāìghī al-Sanjī 19

Al-Sālār, Husām al-Dīn 10-11

Saljuqs $\quad 7,9,12,16$

Al-Sam‘ānī, 'Abd al-Karīm 12, 13, 19

Al-Sam‘ānī, 'Abd al-Rahīm 19

Samarqand $8,12,15^{-17}, 18,21,23$

Sanj 19n

Sanjar ibn Malik Shāh $\quad 7,8,13,17$

Al-Sāwī, 'Umar ibn Sahlān $\quad 8$, 9, 10, 15, 25, $48 \mathrm{n}, 8 \mathrm{o}-81$

Shāfi'ism, Shāfi'is $\quad$ 12-13, 18n, 26-28, 33n, 43

Al-Shahrastānī $\quad 8-9,17,32,163$

Al-Shihābiyya, al-Khānqāh $\quad 13 n$

Shiraz 19

Al-Shirwānī, Shams al-Dīn 13

Shushtar 15, 19

Sufism 41

Sunnism 1, 9, 30, 43, 84-85

Al-Tabrīzī, Muhammad ibn 'Abd al-Wāḥid 49 
Al-Tahānawī 141

Al-Taḥtānī 14ın

Taj al-Dīn Mạ̣mūd ibn Muḥammad ibn 'Abd al-Karìm 17, 21

Tashkent 24

Ṭāshköprüzāde 24

Ṭawāwīs 15

Al-Ṭihrānī, Āghā Buzurg 16-17

Transoxania $7,11,12,15^{-16,18,20,169}$

Al-Ṭūsī, Nașīr al-Dīn $\quad 2,4$, 13, 62n, 69n, 70, 119, 173
Al-Ṭūsī, Sharaf al-Dīn $\quad 22$

Al-Tustarī, Badr al-Dīn $\quad$ 2n, 4

Wațwāṭ̂, Rashīd al-Dīn $\quad$ 17, 61

Yāqūt al-Ḥamawī 18-19

Yazd 8, 19

Al-Ẓahīrī al-Samarqandī $\quad$ 16n

Zarq 19

Al-Zarqī, 'Abd al-Rashīd 19 